I 892 , pp. 294-298) occurred in 1892 , greater in fact than had heretofore been recorded. None similar has taken place since, so far as I know. Yet one hundred miles north of Cape Hatteras, N. C., and fifty miles from land, Phalaropes abound in countless myriads in May.

\title{
STATEN ISLAND CROWS AND THEIR ROOSTS.
}

BY WILliAM T. DAVIS.

Able-bodied Crows do not roost on Staten Island in winter, but fly as night approaches to better protected retreats in New Jersey. In ordinary winters five or six hundred visit the island daily, and generally repair to the South Beach where they find a considerable store of food, in the fish, crabs, and other dead creatures that are cast ashore. As the afternoon wears away, the Crows fly westerly from the beach, and congregate on the salt meadows along Fresh Kill, on the opposite side of the island. If these meadows are covered with snow, they assemble in the trees, or in some upland field, which is more likely to be bare. Here, with additions to their number from other parts of the island, they hold a convention, and gradually, by twos and by threes, and in small flocks, fly either along the Kill out to the Sound, or diagonally across Long Neck to New Jersey, to a roost that lies north or northwest of Staten Island.

Many afternoons have been spent in watching the Crows at Long Neck and elsewhere on the island, and a few specific observations will be offered as evidence here, though a more detailed account is to be found in the Proceedings of the Natural Science Association of Staten Island, for May 1 2, I $\$ 94$.

Sunday, December 24, and Christmas day, I893, were both very mild; there was a warm wind and no snow on the ground. On these occasions several hundred Crows gathered on the salt meadows in the afternoon, near the head of the main branch of 
the Fresh Kill. On the $24^{\text {th }}$ it was cloudy and showered occasionally and the Crows commenced flying to New Jersey at 3 P. $\mathbf{M}$. The $25^{\text {th }}$, on the contrary, was a bright sunny day, and the first Crows did not start until 3.30 P. M. On this last occasion I counted 303 Crows flying over at right angles to the Turnpike and thence over Chelsea and Dongan Island, like a long straggling caravan following an aerial highway.

They do not take exactly the same path always; occasionally some follow the Kill, as has been stated above, and those that fly across the Neck are governed considerably by the direction of the wind. One blustery day in February Mr. Walter Granger and I watched the first Crows fly over the Neck, drop close to the fields in order to avoid the force of the north wind, and finally fly along Chelsea Creek to New Jersey. The birds that followed flew by a more circuituous route, keeping among the scattered timber and thus avoiding the full strength of the gale.

Again, all of the Crows that fly westward from the beach do not cross Long Neck or follow the Kill to the roost situated north or northwest of the island, but a few continue along the high ground from Annadale to Kreischerville, and are apparently bound for a roost that lies beyond the Raritan. On calm days they may be watched for miles with a glass, as they fly sky high on their journey.

In the severe winter of $1892-93$, Crows not only came from the New Jersey roosts already mentioned, but they also came to the South Beach from the roost at Sandy Hook. They went long distances for food and no doubt many died. Mr. Robert Ridgway, in 'Science' for February Io, I \$93, tells of the sufferings of the Crows in a roost near Washington, D. C., stating that many had their eyes frozen, which was followed by the bursting of the organs and the death of the birds from starvation.

On the afternoon of the $22 \mathrm{~d}$ of January, 1893 , many Crows were noticed near the foot of New Drop lane. Some of these birds flew westward in the direction of Fresh Kill, while several hundred flew over the water to Sandy Hook. The chief departure was about 4 P. M. At fifteen minutes past four they had nearly all gone, but I observed a few belated individuals fly boldly from the Staten Island shore near the light house, without any rest previous to undertaking their long journey. Thus many 
of the Crows that were walking together on the beach flew in opposite directions as the afternoon wore away, and roosted in widely separated parts of New Jersey.

The Rev. Samuel Lockwood, writing of the evergreen groves on Sandy Hook, in the 'American Naturalist' for August, I892, says: "Here are rookeries of crows which almost blacken the air as they return in the evening from their daily foraging." As far as my observation extends it is only in very cold weather that they continue their flight to Staten Island and its store of food on the South Beach.

In spring the Crows return to the island to roost, and mostly fly at evening in two directions, namely, toward Old Place on the North Shore, and toward the woods at Annadale. Of course many build nests and live for a time apart, but as early as April and May, flocks of Crows that have no family cares may be seen at evening about these warm weather roosts and as the season advances the numbers are greatly increased.

At Old Place there is a long ridge of slightly elevated land in the salt meadow, on which stands a thick growth of deciduous trees, and it is in these and in the immediate vicinity that the Crows have the smaller of their warm weather roosts. I have seen them congregate at this place in the late afternoons every summer since $\mathrm{I} 889$, chiefly in a large, dead tree that towers above the surrounding growth, which tree is also used by the Bitterns that occupy the same woods during the day and sally forth on their nightly fishing excursions about the time the Crows come home to roost.

The majority of the Crows that frequent the island in warm weather may be seen flying in late afternoon toward the Annadale woods. They come from the beach, and from all directions, and congregate in the broad open fields near the woods where they have had a warm weather roost for many years. On August 6,1893 , a flock, by count, of over three hundred Crows had gathered in these fields, and many more were in the woods near by, and others constantly arriving. At dusk the Crows in the field flew to the woods. All of them did not roost in a few trees close together, but were scattered about the vicinity in small assemblages.

On the 27 th of November, I 892 , I found only a small flock of about forty Crows remaining in the Annadale roost. At dusk 


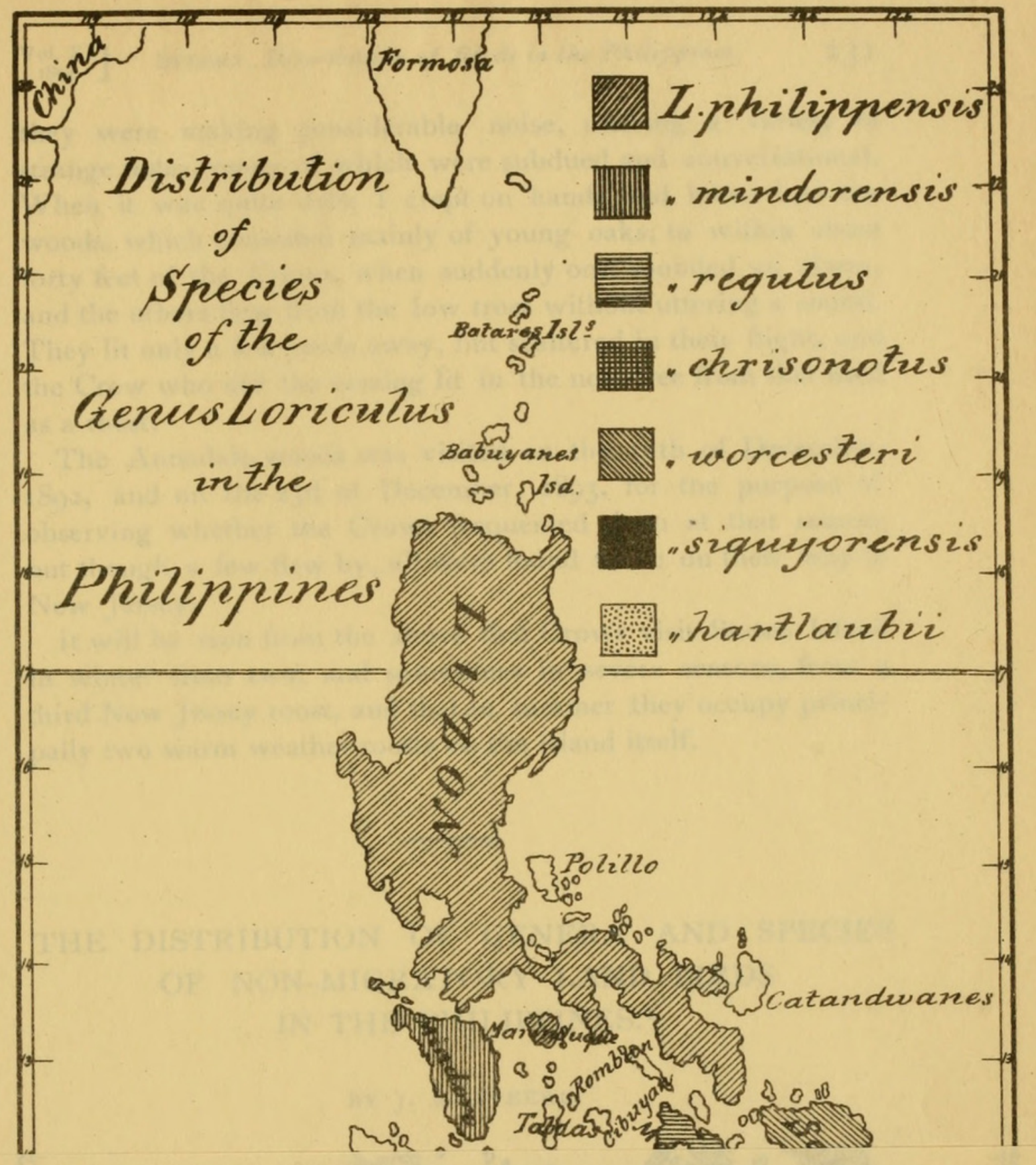




\section{$2 \mathrm{BHL}$ Biodiversity Heritage Library}

Davis, William T. 1894. "Staten Island Crows and Their Roosts." The Auk 11, 228-231. https://doi.org/10.2307/4067742.

View This Item Online: https://www.biodiversitylibrary.org/item/55089

DOI: https://doi.org/10.2307/4067742

Permalink: https://www.biodiversitylibrary.org/partpdf/88609

\section{Holding Institution}

Smithsonian Libraries

\section{Sponsored by}

Smithsonian

\section{Copyright \& Reuse}

Copyright Status: Public domain. The BHL considers that this work is no longer under copyright protection.

This document was created from content at the Biodiversity Heritage Library, the world's largest open access digital library for biodiversity literature and archives. Visit BHL at https://www.biodiversitylibrary.org. 